\title{
Survey of the incidence of tetracycline-resistant haemolytic streptococci between 1958 and 1965
}

\author{
J. V. DADSWELL \\ From the Department of Pathology and Bacteriology, Institute of Laryngology and Otology, London
}

SYNOPSIS The incidence of tetracycline-resistant beta-haemolytic streptococci isolated in the Department of Pathology and Bacteriology of the Institute of Laryngology and Otology, London, during the years 1958-65 is reported. From less than $1 \%$ of all beta-haemolytic streptococci isolated in 1958 they increased to $44 \%$ in 1965 . These findings are discussed.

The increasing incidence of tetracycline-resistant beta-haemolytic streptococci in Britain has been reported on from time to time in the last few years (Parker, Maxted, and Fraser, 1962; Mitchell and Baber, 1965; Robertson, 1965). At present about a third of all beta-haemolytic streptococci isolated from lesions in man are likely to be resistant to tetracycline. Reports from the U.S.A. (Kuharic, Roberts, and Kirby, 1960; McCormack, Kaye, and Hook, 1962) indicate that tetracycline-resistant strains became common there in $1960-61$, but no figures from Britain before 1961 are available. In view of this fact it was thought that a survey of all tetracycline-resistant beta-haemolytic streptococci isolated in one laboratory over the past eight years would prove of interest.

\section{MATERIALS AND METHODS}

The records of the Department of Pathology and Bacteriology of the Institute of Laryngology and Otology for the period 1958-65 were examined, and a note made of Received for publication 12 January 1967. all beta-haemolytic streptococci isolated, and from what source, during this time. The isolations were made from patients attending the associated Royal National Throat, Nose, and Ear Hospital.

The figures represent strains found to belong to Lancefield's group A, either by grouping or by exhibiting sensitivity to bacitracin ( 0.1 units disc, Mast).

During 1960-65 resistance to tetracycline was determined by lack of inhibition of growth around a $10 \mu \mathrm{g}$. disc (Oxoid) on a blood agar plate. Before this the sensitivity was determined by using a filter paper strip impregnated with tetracycline, which was allowed to prediffuse on a blood agar plate. The strains to be tested were subsequently streaked across at right angles.

One isolation only per patient is included, except when resistant and sensitive strains were both isolated.

\section{RESULTS}

In 1958 one tetracycline-resistant strain was found in 235 isolates. The proportion of resistant strains remained relatively low until 1961 when there was a threefold increase. This was followed by a further rapid increase in 1962-63 which was not, however,

TABLE

\begin{tabular}{|c|c|c|c|c|c|c|c|c|c|c|c|c|c|c|c|}
\hline \multicolumn{2}{|l|}{1958} & \multicolumn{2}{|l|}{1959} & \multicolumn{2}{|l|}{1960} & \multicolumn{2}{|l|}{1961} & \multicolumn{2}{|l|}{1962} & \multicolumn{2}{|l|}{1963} & \multicolumn{2}{|l|}{$1964^{1}$} & \multicolumn{2}{|l|}{1965} \\
\hline $\begin{array}{l}\text { Total } \\
\text { Iso- } \\
\text { lated }\end{array}$ & $\begin{array}{l}\text { Tetra- } \\
\text { cycline } \\
\text { Resistant }\end{array}$ & $\begin{array}{l}\text { Total } \\
\text { Iso- } \\
\text { lated }\end{array}$ & $\begin{array}{l}\text { Tetra- } \\
\text { cycline } \\
\text { Resistant }\end{array}$ & $\begin{array}{l}\text { Total } \\
\text { Iso- } \\
\text { lated }\end{array}$ & $\begin{array}{l}\text { Tetra- } \\
\text { cycline } \\
\text { Resistant }\end{array}$ & $\begin{array}{l}\text { Total } \\
\text { Iso- } \\
\text { lated }\end{array}$ & $\begin{array}{l}\text { Tetra- } \\
\text { cycline } \\
\text { Resistant }\end{array}$ & $\begin{array}{l}\text { Total } \\
\text { Iso- } \\
\text { lated }\end{array}$ & $\begin{array}{l}\text { Tetra- } \\
\text { cycline } \\
\text { Resistant }\end{array}$ & $\begin{array}{l}\text { Total } \\
\text { Iso- } \\
\text { lated }\end{array}$ & $\begin{array}{l}\text { Tetra- } \\
\text { cycline } \\
\text { Resistant }\end{array}$ & $\begin{array}{l}\text { Total } \\
\text { Iso- } \\
\text { lated }\end{array}$ & $\begin{array}{l}\text { Tetra- } \\
\text { cycline } \\
\text { Resistant }\end{array}$ & $\begin{array}{l}\text { Total } \\
\text { Iso- } \\
\text { lated }\end{array}$ & $\begin{array}{l}\text { Tetra- } \\
\text { cycline } \\
\text { Resistant }\end{array}$ \\
\hline $\begin{array}{l}150 \\
31\end{array}$ & $\begin{array}{l}1(0.7 \%) \\
0\end{array}$ & $\begin{array}{l}196 \\
60\end{array}$ & $\begin{array}{l}2(1 \%) \\
2(3 \%)\end{array}$ & $\begin{array}{l}118 \\
39\end{array}$ & $\begin{array}{l}3(3 \%) \\
1(3 \%)\end{array}$ & $\begin{array}{l}139 \\
35\end{array}$ & $\begin{array}{l}17(12 \%) \\
5(14 \%)\end{array}$ & $\begin{array}{l}118 \\
36\end{array}$ & $\begin{array}{l}28(24 \%) \\
7(19 \%)\end{array}$ & $\begin{array}{l}118 \\
35\end{array}$ & $\begin{array}{l}48(41 \%) \\
10(29 \%)\end{array}$ & $\begin{array}{l}171 \\
46\end{array}$ & $\begin{array}{l}61(36 \%) \\
21(45 \%)\end{array}$ & $\begin{array}{l}173 \\
55\end{array}$ & $\begin{array}{l}71(41 \%) \\
21(38 \%)\end{array}$ \\
\hline $\begin{array}{l}40 \\
1 \\
5 \\
8\end{array}$ & $\begin{array}{l}0 \\
0 \\
0 \\
0\end{array}$ & $\begin{array}{l}97 \\
9 \\
4 \\
9\end{array}$ & $\begin{array}{l}0 \\
0 \\
0 \\
0\end{array}$ & $\begin{array}{l}51 \\
6 \\
7 \\
2\end{array}$ & $\begin{array}{l}2(4 \%) \\
0 \\
0 \\
0\end{array}$ & $\begin{array}{l}96 \\
6 \\
10 \\
1\end{array}$ & $\begin{array}{l}7(7 \%) \\
0 \\
1(10 \%) \\
0\end{array}$ & $\begin{array}{l}66 \\
12 \\
7 \\
5\end{array}$ & $\begin{array}{l}16(24 \%) \\
4(33 \%) \\
2(29 \%) \\
1(20 \%)\end{array}$ & $\begin{array}{l}54 \\
8 \\
4 \\
7\end{array}$ & $\begin{array}{l}23(43 \%) \\
5(63 \%) \\
1(25 \%) \\
5(71 \%)\end{array}$ & $\begin{array}{l}72 \\
15 \\
7 \\
0\end{array}$ & $\begin{array}{l}33(46 \%) \\
13(8 \%) \\
3(43 \%) \\
0\end{array}$ & $\begin{array}{l}94 \\
5 \\
7 \\
3\end{array}$ & $\begin{array}{l}43(46 \%) \\
5(100 \%) \\
4(57 \%) \\
3(100 \%)\end{array}$ \\
\hline 235 & $1(0.4 \%)$ & 375 & $4(1 \%)$ & 223 & $6(3 \%)$ & 287 & $30(10 \%)$ & 244 & $58(24 \%)$ & 226 & $92(41 \%)$ & 311 & $131(42 \%)$ & 337 & $147(44$ \\
\hline
\end{tabular}

Figures for 1964 included by kind permission of the Editor of the Lancet. 
maintained in 1964-65, when the proportion of tetracycline-resistant strains isolated remained fairly constant.

As can be seen from the table, there was no preponderance of resistant strains from any one source, the rates of isolation from ears, noses and sinuses, and throats being roughly comparable. In the last three years, however, there has been a consistent high rate of isolation from infected surgical wounds.

\section{DISCUSSION}

Although no records earlier than 1958 were examined, it would seem unlikely that resistant strains appeared in any numbers at that time. The isolation of resistant strains became a common occurrence during 1961-62, a finding which agrees with that of Parker et al. (1962), although about a year later than the comparable increase observed in the U.S.A. The rapid increase in the numbers of such strains that occurred in 1962-63 was not subsequently maintained, so that any further increase seems likely to be of a gradual nature.

Mitchell and Baber (1965) report a 32\% incidence of resistant strains in the Bristol area in 1963-64 and comment on the high incidence in cases of acute otitis media. Robertson (1965) gives an incidence of $31 \%$ over a similar period in south-west
Essex and also notes the high rate of isolation from $\stackrel{0}{\vec{*}}$ infected ears. The figures presented here give a higher overall incidence for this period, which may $\underset{\Rightarrow}{\vec{P}}$ perhaps be accounted for by the fact that the isolations were made from patients attending a hospital specializing in diseases of the ear, nose, and throat. A particularly high rate of isolation from ears has not, however, been observed. There is agreement that beta-haemolytic streptococci causing wound os infections are especially likely to be tetracycline $\overrightarrow{0}$ resistant.

There can be no doubt that tetracycline-resistant $\vec{\omega}$ strains are now distributed widely throughout the population; the implications regarding the treatment of beta-haemolytic streptococcal infections $\underset{O}{O}$ are obvious.

My thanks are due to the surgeons of the Royal National Throat, Nose and Ear Hospital for providing the material 음 from their patients; to Professor I. Friedmann for helpful advice; and to the technical staff of the Department of $c$ Pathology and Bacteriology for their valuable assistance.

\section{REFERENCES}

Kuharic, H. A., Roberts, C. E., Jr., and Kirby, W. M. (1960). J. Amer. med. Ass., 174, 1779.

McCormack, R. C., Kaye, D., and Hook, E. W. (1962). New Engl. J. Med., 267, 323.

Mitchell, R. G., and Baber, K. G. (1965). Lancet, 1, 25.

Parker, M. T., Maxted, W. R., and Fraser, C. A. M. (1962). Brit. med. J., $1,1550$.

Robertson, M. H. (1965). Ibid., 2, 569. 